УДК 375.5.016:82(082)

DOI: 10.37026/2520-6427-2020-103-3-110-113
Галина МЕЛЬНИКОВИЧ, старший викладач кафедри суспільно-гуманітарної освіти

Рівненського ОІППО

\title{
ФОРМУВАННЯ \\ КОМПЕТЕНТНОЇ ОСОБИСТОСТІ УЧНЯ ЗАКЛАДУ ЗАГАЛЬНОЇ СЕРЕДНЬОЇ ОСВІТИ НА УРОКАХ УКРАЇНСЬКОЇ ЛІТЕРАТУРИ
}

\begin{abstract}
У статті окреслено шляхи формування компетентної особистості учня 33 СО на уроках украӥнської літератури. Наведено приклади інтерактивних методів $і$ прийомів, щзо впливають на формування такої особистості, доведено дочільність їх використання в освітньому проиесі.

Ключові слова: компетенція, компетентність, компетентна особистість, літературна компетенція.

В статье обозначены пути формирования компетентной личности ученика $3 О С О$ на уроках украинской литературы. Приведены примеры интерактивных методов и приемов, влияющих на формирование указанной личности, доказана иелесообразность их использования в образовательном процессе.
\end{abstract}

Ключевые слова: компетенция, компетентность, компетентная личность, литературная компетенция.

The article is devoted to the elucidation of the essence of the formation of a competent personality by means of Ukrainian literature. The ways of formation of key competencies are revealed and characterized. Their features and expediency of use in the educational process are analyzed. The essence of the competence approach to learning and the concepts of «competence» and «competence» are clarified. The structure of literary competence is given, which provides for the formation of students' worldview, morals and civic position, conscious use of acquired knowledge in literature lessons, which form the key competence of "lifelong learning" through the ability to talk, solve problems.

Formation of understanding of Ukrainian literature as an organic component of native culture, awareness of the specifics of literature as an art of speech, knowledge of literary works planned for textual study, main stages and phenomena of literary process, basic facts of life and work of outstanding writers, ability to analyze and interpret literary work in its unity content and form; to compare multinational literary texts, understanding the author's position and ways of its expression, the use of theoretical and literary concepts when working on the text of a work of art, the development of skills to create oral and written creative works.

The development of interest in fiction and systematic reading, with the help of language and literature of national and universal values, the formation of a humanistic worldview of the individual, expanding its cultural and cognitive interests, educating students in love, respect for the traditions of the Ukrainian people, tolerant attitude to cultural traditions peoples.

Through the prism of the student's activity, analogies are made between what is depicted in the work and what we observe in real life. It is possible to use the considered situations in personal life, project your future according to the circumstances in which the hero of the literary work is rethinking the structure of the educational process, the transition to solving the problem of development and realization of creative abilities of each student.

Key words: competence, competence, competent personality, literary competence.

Постановка проблеми. Сьогодні перед освітою, зокрема закладами загальної середньої освіти (далi-33CO), стоїть надважливе завдання - сформувати людину, здатну приймати відповідальні рішення, критично мислити, творчо вирішувати проблеми, самореалізуватися, тобто компетентну особистість. Питання формування компетентностей висвітлено в Законі України «Про освіту», Концепції Нової української школи, Концепціях мовної та літературної освіти, Державному стандарті базової і повної загальної середньої освіти, нових програмах.

Важливим нині $є$ не тільки вміння оперувати власними знаннями, а й бути готовим змінюватися й пристосовуватися до нових потреб ринку праці, оперувати й управляти інформацією, активно діяти, 
швидко приймати рішення, навчатися впродовж життя. Таким чином, творчо проєктуючи своє життя, особистість оволодіває не лише знаннями, а й компетентностями.

Традиційна освітня парадигма, основою якої ще донедавна були знання, вміння і навички, сьогодні поступається місцем новій, в основі якої - формування життєвих компетентностей зростаючої особистості (знання, вміння, життєвий досвід особистості, їі життєтворчі здатності, необхідні для розв'язання життєвих завдань і продуктивного здійснення життя як індивідуального життєвого проєкту), що передбачає мобільність знань, гнучкість методів і критичність мислення, тобто здатність використовувати набуті знання та вміння на вищому рівні, переносити їх у різні життєві ситуації, застосовувати на практиці.

Аналіз наукових досліджень і публікацій. Питання використання компетентнісного підходу в освіті сьогодні є надзвичайно актуальним. Праці А. Андреєва, І. Зимньої, І. Срмакова, О. Овчарук, О. Павленко, О. Пометун, Л. Паращенко, О. Савченко та інших науковців стали першоосновою у розв'язанні означеної проблеми. У методиці викладання української літератури до проблем формування літературної компетентності зверталися Л. Мозгова, А. Фасоля, Л. Фурсова, В. Шуляр, Т. Яценко та ін., а вивченню життєвої компетентності присвятили свої розвідки Л. Мітіна, Д. Пузікова, І. Єрмаков, І. Ящук та ін.

Незважаючи на чималу кількість досліджень, проблема формування компетентнісної особистості учня З3СО на уроках української літератури лишається актуальною й нині, що й зумовило написання означеної статті.

Мета статті - окреслити шляхи формування компетентної особистості учня $33 \mathrm{CO}$ на уроках української літератури; запропонувати приклади інтерактивних методів і прийомів, що впливають на формування компетентної особистості учня.

Виклад основного матеріалу. Поняття «компетентність», «компетенція», «компетентнісний підхід» уже давно не $є$ новими у вітчизняній освіті, навпаки вони активно використовуються у ході викладання різних навчальних дисциплін. Серед них ключова роль відведена українській літературі, адже саме цей предмет найглибше проникає у свідомість і підсвідомість зростаючої особистості, торкаючись найтонших струн її душі.

Сутність компетентнісного навчання полягає в спрямуванні освітнього процесу на набуття учнями важливих компетентностей. У зв'язку з цим, посилаючись на Великий тлумачний словник сучасної української мови, під компетенцією розумітимемо «добру обізнаність у чомусь; коло повноважень певної організації, установи чи особи; загальну здатність, щзо базується на знаннях, досвіді, цінностях $і$ здібностях, набутих завдяки навчанню», а під компетентністю «загальну здатність особистості застосовувати набуті знання, вміння, навички, способи діяльності, власний досвід у нестандартних ситуаціях із метою розв'язання певних життєво важливих проблем» [2, с. 560]. Схожість представлених понять не $є$ випадковістю, адже вони походять від латинського слова competentia (узгодженість, відповідність) та competo (відповідати, бути гідним, здатним до чогось) [6].
А що ж таке «літературна компетениія»? Зважаючи на те, що тлумачні словники не подають значення цього словосполучення, але пам'ятаючи, що «компетенція» традиційно вживається у значенні «коло повноважень», а «компетентність» - «обізнаність, авторитетність, кваліфікованість», під літературною компетенцією розумітимемо «інтегрований результат навчальної діяльності учнів, який базується на сумі знань, отриманих у проиесі літературної освіти, і виявляється в уміннях, необхідних для сучасного життя, вміння мобілізувати в певній ситуації набуті знання і досвід» [8].

«У кожній людині є сонце ... Тільки не треба його гасити», - саме цей вислів мудреця Сократа став девізом у проведенні уроків української літератури, що забезпечують компетентнісний підхід у навчанні, виховують особистість, здатну приймати відповідні рішення, критично мислити, творчо вирішувати проблеми, самореалізуватися, стимулюють розвиток певних життєвих компетентностей учнів.

Завдання, які ми ставимо перед собою у процесі вирішення проблеми формування літературної компетенціі:

- збагатити учнів новими знаннями культурного, загальнолюдського, літературного характеру;

- формувати національну самосвідомість школярів;

- урахувати когнітивну структуру особистості;

- формувати вміння інтерпретувати художні твори, належно поціновувати їх, визначати художню вартість;

- доповнювати життєвий досвід учнів розумінням ментальних рис своєї нації [8].

Отже, важливо допомогти зростаючій особистості «не просто виживати, а повноцінно жити в сучасному світі». На тлі сучасного світового літературного життя українські мистецькі взірці повинні бути піднесені на престижну висоту, щоб наші діти за допомогою отриманих знань могли знайти себе в цьому житті, використати набуті вміння, знайти їм практичне застосування, оскільки літературна освіта сприяє формуванню особистості, здатної до життєтворчості.

У ході роботи з учителями української мови та літератури на курсах підвищення кваліфікації у Рівненському обласному інституті післядипломної педагогічної освіти (далі - РОІППО) акцентуємо увагу на тому, що кожен урок несе певний обсяг інформаціï, і саме від учителя залежить наскільки ії можуть сприйняти та засвоїти учні, якими навчальними методами та прийомами при цьому варто скористатися.

Надзвичайно цікавою в роботі з курсантами $є$ така форма роботи, як конференція з обміну досвідом. Слухачі діляться досвідом, із радістю презентують свої досягнення, аналізують недоліки. Зокрема, у ході такої роботи колеги-філологи доводять думку про те, що саме уроки літератури формують ключову компетентність «навчання впродовж життя» шляхом уміння вести бесіду, вирішувати проблемні завдання, наголошують на здатності учнів проводити аналогії між зображеним у творі та тим, що спостерігаємо насправді, на можливості використання розглянутих ситуацій у реальному житті, проєктувати своє майбутнє відповідно до обставин, в яких перебуває герой літературного твору. При цьому їхнє основне завдання як учителя - допомогти учням знайти себе в житті; 
пробудити чи розвинути те творче зернятко, яке є в кожній дитині, закладене в неї природою. Вчителі-філологи підкреслюють, що аналіз літературного твору буде цікавим для школяра лише в тому випадку, якщо він пробуджує певні асоціації, пов'язані з його світосприйманням, емоційними потребами, життєвими проблемами.

Працюючи з учителями на курсах підвищення кваліфікації в РОІППО, пропоную їм на деякий час перевтілитися в учнів і виконати завдання, які, як засвідчує практика, сприяють розвитку дитячої думки, змушують осмислювати ситуацію й робити висновки, іноді навіть несподівані для самого себе. При цьому вчителі-практики пересвідчуються, що учень, напружуючи свій розум, ніби сам стає вчителем, а вчитель відповідно - перетворюється на організатора і консультанта у процесі такого самонавчання. Проаналізуємо деякі із цих завдань детальніше.

Поміркуйте, чи можлива дана ситуація в наш час? Чому?

1) Хуха-Моховинка із казки В. Короліва-Старого мала можслиість помститися діду за отримані образи, однак изього не зробила. Чи правильно вона вчинила, урятувавши його? Займи позицію «за», «проти», «інше бачення» та обтрунтуй свій вибір.

2) Склади таблицю рис особистості справжнього лідера, керівника - «реальне» $i$ «бажсане» (за казкою І. Франка "Фарбований Лис»). Зроби висновок, доведи свою думку.

3) Казка «Фарбований Лис» Івана Франка закінчується трагічно. Чи справедливо покарали героя? Як би ти покарав його?

4) Старший та середній брати із думи «Втеча трьох братів з города Азова, з туреиької неволі» виявляли милосердя до меншого брата, залишаючи сліди у вигляді тернового гілля, иматків одягу. Доведи або спростуй ичю думку.

Такі завдання орієнтують учня на ідентифікацію себе $з$ літературним персонажем, спонукають до глибокого усвідомлення психології героїв, створення власної інтерпретації моделей їхніх образів.

Проблемне навчання - одне із ключових у практиці навчання літератури. Починаючи вивчення теми, перед дітьми ставиться проблемне питання, яке вони осмислюють упродовж усього уроку, наприклад:

1) «Маруся Богуславка - героїня чи зрадниия рідного народу?» (дума «Маруся Богуславка»);

2) «Чи легко бути не таким, як усі?» (оповідання В. Дрозда «Білий кінь Шептало»);

3) «Еміграчія - че зрада чи необхідність, прагнення людини до самореалізації?» (новела В. Стефаника «Камінний хрест»);

4) «Чи винні батьки в смерті Федька?» (оповідання В. Винниченка «Федько-халамидник»);

5) «Чи завжди сміливі мають щастя?» (повість I. Багряного «Тигролови»).

До проблемних питань звертаємося і під час опрацювання твору, наприклад: «Григорій Многогрішний - украӥнський супермен чи приклад для наслідування?» (повість I. Багряного «Тигролови»).

Для формування літературних компетенцій варто застосовувати інтерактивні прийоми, наприклад: «Bidгадай літературного героя», «Літературний крос» (доповнити незавершені вислови необхідними відомостями). Такі завдання розвивають в учнів уміння вчитися, висловлювати власну думку та вислуховувати думки інших, формують навички, необхідні для життєвого вибору.

Уроки української літератури проходять набагато продуктивніше і цікавіше, якщо використовувати прийоми, які потребують різних форм організації учнів, як-от: «Займи позииію», "Поетична хвилинка», «Аукиіон думок», «Доведи або спростуй» та ін. Неабияк зацікавлює учнів гра "Діалог із літературним героєм». Один з учнів виконує роль літературного персонажа, перевтілившись у його образ, виходить на середину класу і вступає в діалог з однокласниками. При цьому вони задають йому запитання, зокрема створюють різні вигадані ситуації. Завдання «літературного героя» - правильно зіграти відведену йому роль, обгрунтувати свої вчинки й думки так, щоб усі інші повірили йому.

Переконана, що жодна дитина не буде байдужою до завдань, що вимагають дослідження, застосування творчих здібностей, наприклад:

- написати листа від імені одного персонажа іншому або письменнику (звірі з казки I. Франка пииуть листа Фарбованому Лису);

- стати співавтором твору, увести себе у твір як героя, розказати про події, свої вчинки, думки від імені героя твору (розповідь Мирослави про своє життя, чому вона не стала зрадницею - за повістю I. Франка «Захар Беркут»);

- домислити події, які передували зображеним, придумати різні варіанти закінчення твору (за думою «Маруся Богуславка») [4].

Уроки літератури є плодотворним грунтом для формування вмінь вести бесіду, вирішувати проблемні завдання. У кожному творі є художня деталь, яка збудить уяву читачів, змусить задуматися, провести аналогії із сучасним життям. Так, на уроках української літератури можна запропонувати учням уявити себе журналістами, взяти інтерв'ю в батьків на теми, пов'язані з вивченням того чи іншого художнього твору. Наприклад, як би вчинили ваші батьки, уявляючи себе на місці матері й батька головної героїні поеми Т. Шевченка «Катерина».

Формуванню творчої компетентності сприяє використання кооперативних форм навчання, адже учні, працюючи в парах або групах, шукають шляхи розв'язання проблеми, аналізують ситуацію, діляться думками, досвідом, роблять висновки, вчаться співпрацювати, цінувати думку товариша тощо. Найчастіше створюються групи «літературознавців», «істориків», «етнографів», «психологів», «біографів», «експертів», «краєзнавців», «народознавців» та ін. Саме таке спрямування спонукає дітей до пошуку потрібної інформації, сприяє розширенню кругозору, формуванню вміння критично мислити, систематизувати матеріал, презентувати його класу.

Так, під час опрацювання п’єси «Наталка Полтавка» I. Котляревського «історики» досліджують історію написання твору; «етнографи» побут українців; «психологи» - характер літературних персонажів; «фольклористи - значення народних пісень, приказок, прислів ’їв у тексті твору; 
«народознавці» - народні звичаї, обряди. Саме таке «вживання» в роль допомагає розвивати творчі здібності школярів і спонукає їх глибше усвідомити мистецьке явище. Цікаві творчі завдання підвищують прагнення проникнути у творчу лабораторію письменника, концентрують увагу на сюжеті, стилі твору, його композиції, образах, навчають уважно, з повагою ставитися до слова великих майстрів літератури, що надалі, безумовно, допомагає їм в осмисленні та аналізі низки інших літературних проблем [5].

В умовах безперервного навчання найголовніше завдання школи - навчити школярів навчатися самостійно, самостійно здобувати знання, щоб у майбутньому адаптуватися в суспільстві. Для цього на уроках української літератури потрібно сформувати в учнів такі вміння:

- прочитавши твір, уміти визначити проблеми, які порушуються, самостійно та критично їх аналізувати;

- усвідомлювати, де в життєвих ситуаціях можна використати здобуті знання і вміння;

- уміти працювати з текстом твору, добирати факти, художні деталі, аналізувати їх, робити висновки й узагальнення;

- уміти працювати в колективі над розв'язанням проблем, поставлених однокласниками;

- уміти користуватися знаннями, одержаними поза школою (радіо, телебачення, Інтернет тощо) [1].

У чому ж полягає особливість моєї роботи на лекціях з учителями-філологами? У процесі організації освітньої діяльності, через відеопрезентації, слайди, різноманітні завдання, які поєднують раціональні та емоційні види діяльності, надають простір ініціатив учнів, закликаю колег до гнучкості у виборі прийомів, нестандартності, створення ситуацій, які допоможуть «оживити» уроки (враховуючи при цьому освітні потреби дітей, їхні індивідуальні здібності, психологічні особливості), уникати одноманітності, оскільки до їхніх послуг сьогодні величезна кількість різноманітних педагогічних технологій, орієнтованих на творчий розвиток компетентної особистості.

Розділяю думку відомого педагога Бориса Степанишина, що «творчість потрібно розуміти не як ланцюг суспільних методичних винаходів, а як постійне прагнення уникати стандарту, трафарету, одноманітності, що вбиває іскринки пізнавального дитячого зацікавлення». Як приклад, пропоную вчителям прикарпатську легенду, в якій майстер за кожне наступне вирізьблене ним крісло вимагав від пана подвійної платні й так пояснив свої дії: «Стіл і одне крісло буде мені ияікаво і приємно вирізьблювати, бо я щзе такого не робив. Цікаво добирати узір, чекати, що з того вийде, пережсиати. Друге крісло дається мені важче, бо я вже ияю роботу знаю. Третє якось домучу..., а ось четверте... Коли я вирізьблю узір (такий самий на четвертому кріслі), то зненавиджу і різьбу, і себе, і все на світі» [5].

Саме через різноманітні форми і методи роботи, їх чергування, постійно підтримуючи інтерес до книги i читання, спонукання до самостійного пошуку, активності, вибору життєвої позиції, розвитку комунікативних умінь, варто формувати компетентну особистість.
При цьому головним є не предмет, якому ми навчаємо, а особистість, яку формуємо. Не предмет формує особистість, а вчитель - своєю діяльністю, пов'язаною із вивченням предмета.

Висновки. Узагальнюючи вищезазначене, можемо зробити висновок, що запровадження компетентнісного підходу в освіті - важливе завдання, покладене на сучасну школу, адже забезпечує настанову не на процес навчання, а на досягнення особистого результату учня, кардинально змінює його освітню роль - учень перетворюється на активного учасника освітнього процесу, самостійного суб'єкта навчальної діяльності, котрий здобуває, перевіряє, обробляє та використовує інформацію.

Формування компетентної особистості на уроках української літератури - це формування свідомої людини нового часу - високоосвіченої, суспільно активної, ініціативної, творчої, конкурентоспроможної, здатної діяти, генерувати нові ідеї, приймати нестандартні рішення, відповідати вимогам часу.

Подальші наші дослідження плануємо присвятити дослідженню методичної майстерності вчителя-словесника, оскільки особистості, якій притаманна здатність сміливо обирати форми і методи роботи, здатна неабияк вплинути на формування духовного світу учнів.

\section{СПИСОК ВИКОРИСТАНОЇ ЛІТЕРАТУРИ}

1. Варьєва М. Формування життєвої компетентності учнів на уроках української мови й літератури. URL: https://naurok.com.ua/formuvannya-zhittevih-kompetentnostey-uchniv-na-urokah-ukra-nsko-movi-y-literaturi-126237.html (дата звернення: 10.05.2020).

2. Великий тлумачний словник сучасної української мови / уклад. і гол. ред. В. Бусел. Київ ; Ірпінь : ВТФ «Перун», 2009. 1736 с.

3. Концепція «Нова українська школа». URL: https://www.kmu.gov.ua/storage/app/media/reforms/ ukrainska-shkola-compressed.pdf (дата звернення: 25.05.2020).

4. Панченко О. Компетентісний підхід до вивчення української мови та літератури. URL: https://naurok. com.ua/opis-vlasnogo-dosvidu-kompetentisniy-pidhiddo-vivchennya-ukra-nsko-movi-ta-literaturi-103796. html (дата звернення: 10.05.2020).

5. Пометун О. Дискусія українських педагогів навколо питань запровадження компетентністного підходу в українській освіті. Основна школа. 2005. Вип. 3/4.

6. Словник іншомовних слів / уклад. Л. О. Пустовіт. Київ : Довіра, 2000. 1018 с.

7. Степанишин Б. Дума про школу: літературна освіта й естетичне виховання учнів 5-12 класів загальноосвітньої школи. Рівне, 2004. 56 с.

8. Черкаська С. Шляхи формування літературної компетентностінаурокахукраїнськоїлітератури. URL: https://naurok.com.ua/shlyahi-formuvannya-literaturnokompetentnosti-na-urokah-ukra-nsko-literaturi-120337. html (дата звернення: 10.05.2020).

Дата надходження до редакиіï: 22.06.2020 p. 